\title{
カリクスシウ 骨代謝異常の臨床
}

\section{I. 基礎的事項 \\ 2. 原発性副甲状腺機能六進症のスクリーニング \\ 紫芝 良昌}

\section{はじめに}

血中Caが正確に測定され，かつ血中の intact PTHがimmunoradiometric assay法によって正 確に測定されるようになったので，副甲状腺機能 六進症の診断は論理的に注注完全なるのになっ た. 血中イオン化カルシウムが正常より高く，か つintact PTHが正常より高い場合は原発性副甲 状腺機能六進症以外には考えられないからであ る.そして，しばしば説明として，図1のような 図が用いられる1)。正常では血中Caが上昇すれば intact PTHは減少する。逆に血中Caが低下寸れ ばintact PTHは上昇する。これは正常のCaと PTHの間にfeed back関係が存在するからであ る. intact PTHが増加して血中Caが上昇するの は副甲状腺機能元進症以外にないから, 図 1 (A) の部分の検査成績を持つ人は原発性副甲状腺機能 穴進症しか考えられないことになる。

理論的にはまさにその通りである。どこかです でに副甲状腺機能え進症と診断された患者が病院 に来院して，さらに診断を確かめるといらなら， 血中 $\mathrm{Ca}$ (多くはTP, Albと同時に測定してイオン

虎の門病院内科：ししば よしまさ

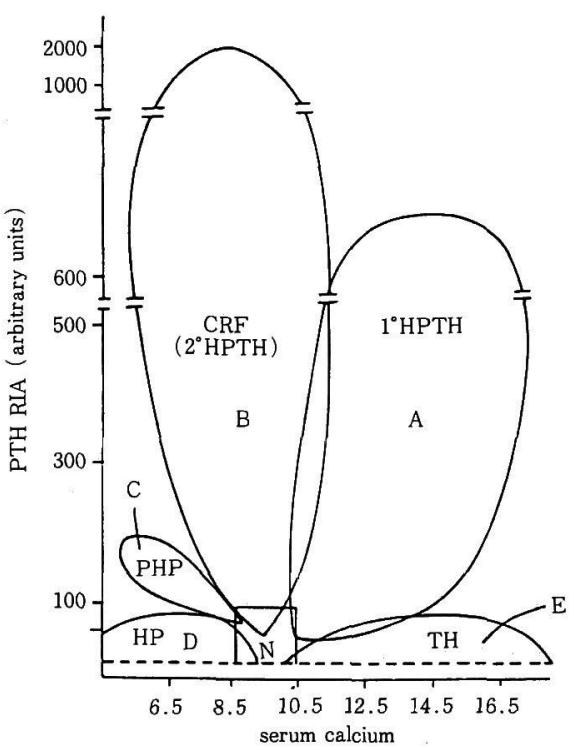

図 1。(文献1)より引用)

A：原発性副甲状腺機能六進症 $\left(1^{\circ} \mathrm{HPTH}\right), \mathrm{B}$ ：慢 性腎炎 (CRF) 等による二次性副甲状腺機能六進症 $\left(2^{\circ} \mathrm{HPTH}\right), \mathrm{C}$ ：偽性副甲状腺機能低下症 (PHP), D : 原発性副甲状腺機能低下症(HP), $\mathrm{N}$ ：正常， E：悪性 腫瘍による高カルシウム血症 $(\mathrm{TH})$

化カルシウムインデックスを計算する)と, intact PTHを同時に測定するのがよいであろら。しか し, 現在, 副甲状腺機能元進症の発見のされ方は 


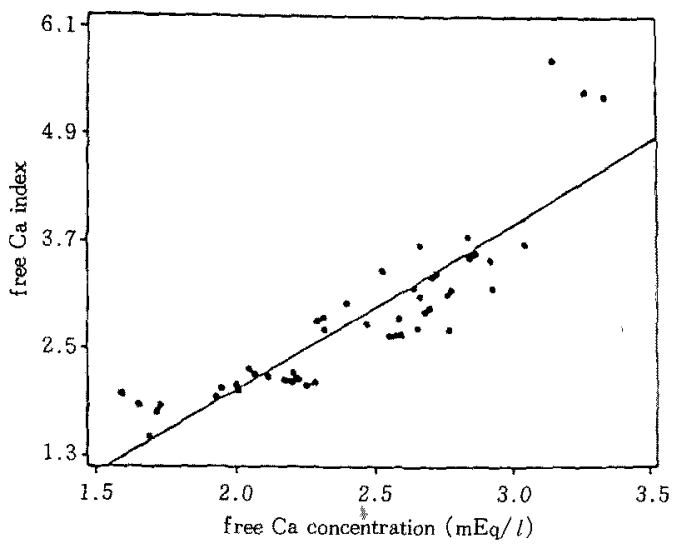

图 2. free $\mathrm{Ca}$ index 上実測梿 穔軸に電極法により測定したfree Ca濃萣，䋖軸に文中 にのベる式より計算したfree $\mathrm{Ca}$ indexを示す。雨者の 相関は極めて良好である。

全くそれとは知らずに病院にきて，たまたまCaを 測定したところ，高Ca血症が偶然に見つかり，精 查の結果, 原発性副甲状腺機能え進症と診断され る例が過半数以上なのである。

血中Caを測定するときに，全例にintact PTH を測定することも理論的には可能であるが，cost performanceを考えると，無駄の多い方法である. 従って、この項ではどうすれば論理的に診断が可 能であるかを論ずるのではなく，どうす㞦ば最む よいcost performanceで原発性副甲状腺機能え 進淀が発兒できるがを論ずることにする。

\section{Free $\mathrm{Ca}$ index}

副甲状腺機能六進症を能率よく発見するには， 入院外来を問わず, 病院で採血した全検体につき， 血中Ca濃度を測定することが有效である，同時に TP, Albの測定が行われていることが多いから free $\mathrm{Ca}$ index $=$

$$
\text { Ca濃度 *(1- } \left.\frac{\mathrm{Alb} * 8+\mathrm{G} 1 * 2+3}{100}\right)
$$

が棓算できる。この数値はよくイオン化カルシウ ム濃度值に一致する(図2）。この他に，註占に揭 げた種々の補正式があるが，我々はイオン化カル シウム濃度に一致するという点から上記の式を用
いている.これをコンピューターKプログラムし ておき，Ca值，TP，ALB值をインブットし，イオ ン化カルシゥム値を得る。検診センターに和ける 正常人の経験から，我々は2.6から3.0までを正常 としている。この值の範围外に出る患者情報が内 科のカルシウムスクリーニング担当者に渡され， そこで次の段階のふるい分けが行われる。

\section{2. 病歴情報による第 2 段階スクリーニン グ}

この段階で入院・外来の患者について病名を険 索する，患者が初誩でない限り，病名から悪性腫 瘍による高Ca血症はある程度見当がつく。㦞性腫 瘍と明確にはされない患者の検体については次に mPTHによる副甲状腺ホルモンの測定を行う。

\section{3. 副甲状腺ホルモンの測定 (mPTH)によ る第 3 段階スクリーニング}

次に検体中の副甲状腺ホルモン測定を行い，原 発性副甲状腺機能六進症の可能性をよりしぼりこ む。多くの場合，オーダーされた測定の項目を測 定し終わり，Ca 測定し終和った血清京たは血漿 険体は，この時まで室温に放置されているか，冷 蔵庫织存されているかのいずれかである，従っ て, 铪体に含まれている1-84PTHは分解がある程 度進んでいると考皇てよいであろう，血清Ca值が 高く，からこれが悪性腫瘍によるすのでない可能

(註 1)現在知られているカルシウム補正式には以下の

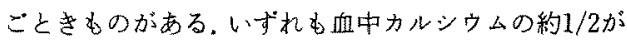
蛋白，特にアルブミンに結合していることから、これを 補正しょうというすのである。

註）種々のカルシウム補正式”

1.カルシウム(補正值mg/di)

$$
\begin{aligned}
= & \text { カルシウム湘定值 }(\mathrm{mg} / \mathrm{dl}) \\
& \text { ーアルプミン }(\mathrm{g} / \mathrm{dl})+4.0
\end{aligned}
$$

(Payne法)

2. カルシウム(補正値 $\mathrm{mg} / \mathrm{dl})$

$$
=\frac{\text { カルシウム測定値 }(\mathrm{mg} / \mathrm{dl})}{0.6+\frac{\text { 総蛋白 }(\mathrm{g} / \mathrm{dl})}{19.4}}
$$


表 1。副甲状腺腺腫また屾過形成

\begin{tabular}{lcc} 
& $(+)$ & $(-)$ \\
FSCI $\geq 3$ and $\mathrm{cPTH} \geq 4$ & 58 & 0 \\
FSCI $<3$ and $\mathrm{cPTH}<4$ & 4 & 2 \\
Diagnostic sensitivity $=93.5 \%$ & & \\
Diagnostic specificity $=100 \%$ & \\
Predictive value of positive test $=100 \%$ & \\
Predictive value of negative test $=33 \%$ & \\
\hline
\end{tabular}

表 2. 副甲状腺機能立進症の臨床症状

\section{尿路結石火上る血尿・疼痛}

骨痛 (osteitis fibrosakよる)

関節痛 (pseudogoutKよる)

胃・十二指腸溃湯

筋力低下（特に四肢近位端），易疲労感

怒りっぽさ，抑らつ状態

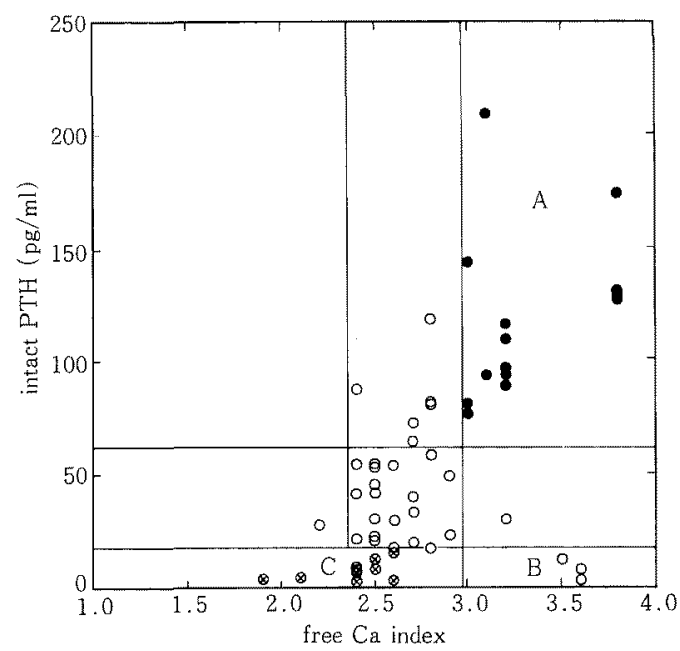

図 3. free $\mathrm{Ca}$ index $z \mathrm{iPTH}$

湘定結果のプロットがAの領域のものはすべて原発性 副腎甲状腺機能六進症(・で表す)であり，Cの領域 のものは, 術後性むらくめて副甲状腺機能低下症 (

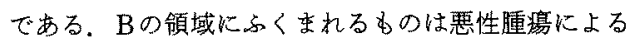
高カルシウム血症である。

性が大であると判定されて，このような検体中の PTHを測定して，これが高值であれば，原発性副 甲状腺機能六進症によるものと判断できる可能性 が高い。しかし，検体中のPTHが分解されている ことを考えると，この検体を材料にintact PTHを 測定することは高価でもあり，無駄でもある。 intact PTHが高值に出た場合には原発性副甲状 腺機能九進症である確率が高いが, intact PTHが 正常玉たは正常以下であっても原発性副甲状腺機 能九進症を否定することは出来ないからである。 そこで，このような場合にはPTHのC端か，また はM端(中間部)を測定するのが適当である。我々 はCa $3.0 \mathrm{mEq} / l$ 以上で，悪性腫瘍が否定されれ ば，副甲状腺機能六進症である確率が高いこと， PTHを測定すると診断がさらに確実になること を確かめて報告した。当初， $\mathrm{PTH}$ のC端(cPTH) 測定をこの目的に使用してスクリーニングを行っ た. 表 1 のごとく, free Ca值(FSCI) $3.0 \mathrm{mEq} / l$ 以 上, $\mathrm{cPTH} 4.0 \mathrm{mIU} / \mathrm{m} l$ 以上を，原発性副甲状腺機 能六進症のcriteria とすると, 有效性の高い鑑別が 出来ることを報告した (表 1$)^{3)}$. 現在ではcPTH測 定よりも，ょり高感度に原発性副甲状腺機能え進 症の検出に適している 用しているが， mPTH值を0.55ng/ml以上とする ことで, 全く同様な鑑別感度を得ることが出来る。

\section{4. 患者本人を呼んでの診察, Ca測定と intact PTHの測定}

上記の段階までで得られた検体が原発性副甲状 腺機能充進症の患者から得られたものかどらか， 大体見当がつくから，次の段階で患者を外来で診 察するか，または病室に訪室して診察する。副甲 状腺機能六進症の諸症状として記載されている諸 症状（表 2) の有無をよく診察するとともに，副 甲状腺腫がないかどうかをよく触れる（意外に触 れる場合が多く，0.8g以上のものは触診で検出で きると考觉てよい).

この段階で血清 $\mathrm{Ca}$, intact PTH（iPTH）を同 時に測定する. free Ca とintact PTHの関係をブ ロットすると, 図 3 のごとくなり，この図からCa が高く, intact PTHが増加しているものは原発性 副甲状腺機能立進症であることがわかる.Caが高 いにもかかわらず, intact PTHの低いものはスク リーニングの段階まで発見されなかった悪性腫煬 (図 1 のE例では肺癌), やimmobilizationによる 高Ca血症である。 


\section{5. 血清Caスクリーニングの効率}

1978年から1980年季での間に我々は原発性副甲 状腺機能元進症を45例発見した。この間に行われ た血清Caの測定は108000検体であるから（病院に おいて採血された検体は汇とえどすべてCaを測 定するので，採血された検体数にほぼ等しい，原 発性副甲状腺機能元進症が発見される頻度は病院 での採血10万検体について 42 人ということにな

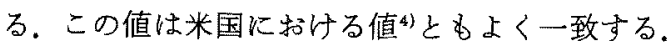
これが効率がよいかどうかは諭議のあるところか もしれないが，現実問題として，副甲状腺機能六 進症を早く発見して対応するには，これしか方法 がないのであって，血清Caの異常が医師のスク
リーニングの眼を逃れることがないよう，工夫を こらす必要があるだるう。

\section{文献}

1) Potts JT: in Harrison's Principles of Internal Medicine 10th Edition, page 1933, McGrawHill, New York 1983.

2）尾形悦郎：カルシウム代謝異常上疾患一血清かル シウム異常症を中心に一。 日内会誌 $81: 340$, 1992.

3) Shishiba $Y$, et al: Significance of parathyroid hormone (PTH) radioimmunoassay in the diagnosis of primary hyperparathyroidism : an experience based on 63 surgically proven cases. Endocrinol Japon $34: 263,1987$.

4) Heath $\mathrm{H}$, et al: Primary hyperparathyroidism. Incidence, morbidity and potential economic impact in a community. New Eng J Med 302, 189, 1980. 